\title{
SOIL-ECOLOGICAL CHARACTERISTICS OF THE RECREATIONAL FOREST ECOSYSTEMS IN MOSCOW
}

\author{
E.A. Dovletyarova ${ }^{1}$, L.V. Mosina ${ }^{2}$, A. Paltseva ${ }^{3,4,5}$, \\ Tatiana Morin $^{3,5}$, P.A. Petrovskaya ${ }^{1}$ \\ ${ }^{1}$ RUDN University \\ Miklukho-Maklay str., 8/9, Moscow, Russia, 117198 \\ ${ }^{2}$ Russian State Agrarian University \\ Timiryazevskaya str., 49, Moscow, Russia, 127550 \\ ${ }^{3}$ Brooklyn College of The City University of New York, \\ Department of Earth and Environmental Sciences \\ 2900 Bedford Avenue, Brooklyn, NY, USA, 11210 \\ ${ }^{4}$ Graduate Center of The City University of New York, \\ $\mathrm{PhD}$ Program in Earth and Environmental Sciences \\ 365 5th Avenue, New York, NY, USA 11016 \\ ${ }^{5}$ New York City Urban Soils Institute \\ 2900 Bedford Avenue, Brooklyn, NY, USA 11210
}

\begin{abstract}
To understand the soil ecology of the forest ecosystem, the dynamics of soil-ecological indicators in the soil-plant system were studied through physical, chemical and biological parameters at various sites of the Forest Experimental Station of the Russian State Agrarian University of Moscow Agricultural Academy; a unique forest ecosystem known for its heavy metal pollution and unregulated recreation. The results showed that soil compaction had the strongest ability to increase risk of heavy metal mobility. Recreational activity caused a 2-3-fold increase in the density of the soil, resulting in poor aeration and significant heavy metal contamination, affecting the stability and functioning of the green spaces. Moreover, the proximity of the urban environment had a negative effect on the state of the stand. The maximum heavy metal migration capacity determined by biological uptake was found in the root systems of 70-80-year-old oak tree stands and the minimum, in the roots of pine and birch phytocoenosis. The systems' normal functions were hindered due to reduction in microbial activity.
\end{abstract}

Key words: heavy metals, compaction, microbiological activity, soil ecological functions, living conditions of a forest stand, recreational load

\section{INTRODUCTION}

Soil plays an important ecological role in maintaining plants' life cycle. Soil is a mixture of different mineral particles, organic matter, and living organisms. Thesoil management influence on dynamic of physical, chemical and biologicalsoil properties [10]. Due to sorption properties, soil has become a sink for many contaminants, and is, therefore, an important source of anthropogenic contamination in urban environments [1]. This fact can have serious consequences considering humans receive about $95-97 \%$ of all food products from soil resources [4].

A large quantity of particulate matter and pollutants settle/accumulate on the soil surface from atmospheric deposition [2]. In 2012, nearly 32 million tons of pollutants, including heavy metals, were released into the atmosphere and these emissions have continued to increase [11]. Lead $(\mathrm{Pb})$ is of particular concern in urban environment due to both its prevalence and toxic effects. Lead can affect nearly all bodily systems and 
is mostly noted for its neurotoxic effects [9]. Interesting to note, at the beginning of the last century in Moscow (1909-1910), total Pb soil concentration was $6 \mathrm{mg} \mathrm{kg}^{-1}$. By the end of the century, its concentration increased by more than 20 times [7].

Unlike in air and water, where heavy metal purification processes occur, soil is an active sink for heavy metals. Biogeochemical processes and storing properties of soil have long-term negative impact on contaminated soils. For example, the period of removal for Pbin the soil is from 740 to 5900 years, $\mathrm{Zn}-70$ to 510 years, $\mathrm{Cd}$ - from 13 to 1100 years, $\mathrm{Cu}$ - from 31 to 1500 years [7]. An accumulation of pollutants in soils, particularly heavy metals, disrupts the proper functioning of the environment, which is a serious threat for organisms, including humans [13].

This study was conducted at the forest experimental station (FES) of the Russian State Agrarian University of Moscow Agricultural Academy (RSAU-MAAT). This forest occupies 232.6 hectares of land and was previously designated as a conservation area both in 1939 and in 1953. Research has been conducted at the FES for over 100 years. This fact provides the baseline and unique opportunity to conduct further research in this large, diverse forest that is situated in an urban environment. The FES is surrounded by a ring of the roads, whose effect imposes a certain imprint on the soil conditions and subsequently, the state of vegetation [8].

In addition to heavy metal pollution posing a risk to the environment, another negative factor is unregulated recreation. In a large portion of the FES, there is a network of trails cutting through and in nearby residential areas, soil cover is practically absent. The wood plantations of the FES that are exposed to these recreation conditions, are extremely depressed, resulting in dieback of the stands, suppressed growth, and substantial damage [6].

In this context, an assessment of the ecological status of the soil and a preservation of its ecological functions requires an integrated research approach to identify the factors affecting the ecological system, especially in terms of environmental pollution. The aim of our study was to conduct comprehensive research on the major soil-ecological characteristics to assess the ecological condition of soils. Environmental indicators were studied through the physical, chemical, agrochemical and biological (including microbiological) parameters in the soil-plant system with a focus on the effect of heavy metal contamination and increased recreational load.

\section{METHODOLOGY}

Soil samples were collected from the experimental plots (the size of $0.5 \mathrm{ha}$ ), in the suburban areas and in the middle of the forest (450 to 500 mapart). Assemblages of plant species and the ground cover on the investigated areas were similar. The controls were located in the Krasnaya and Istra forest in the northern and north-western parts of the Moscow region on the watershed plateau, far from the influence of industrial facilities and highways [7].

The effects of humus and soil acidity as basic soil characteristics were determined by the conventional methods to assess theireffect on the migration of heavy metals and the degree of their mobility in the soil-plant system [5]. Microbial communities were seeded to grow on solid nutrient media in cups in four replications. The quantitative and qualitative compositions of aerobic heterotrophic microorganisms were studied along with the intensity of mineralization processes and the structure of microbial cenosis [5]. 
Group affiliation of actinomycetes were determined with the N.A. Krasilnikova' Finder and A.S. Bondartseva' Scale Colors. The living conditions of the stands were studied as a risk criterion $(\mathrm{J})$ determined by degradation factors. The worse the condition of the stand resulting in dieback, damages, low foliation, the higher the value of J.

To measure the effect of unregulated recreation, bulk density and soil density were sampled every season from the $0-3 \mathrm{~cm}, 3-7 \mathrm{~cm}$, and $7-11 \mathrm{~cm}$ depth intervals as well as from a full $0-10 \mathrm{~cm}$ depth profile. Compaction of the soil layers determines waterair and temperature regimes, redox conditions, and biochemical processes [3]. It also influences basic soil ecological functions, such as growth, development and productivity of plants, microbial activity, and soil fauna [12]. Studyingthe processes that cause changes in the densities of soil horizons is extremely important for understanding the dynamic shifts in the soil environment and forest stands, especially in terms of heavy metal pollution and unregulated recreation.

\section{RESULTS AND DISCUSSIONS}

The studied forest plots located within 5 meters of the urban area were characterized by increased dieback and crippled trees. Such plantations were determined as being on the verge of disintegration and in a weakened state. Soil-ecological characteristics studied under the plantations are presented in Table 2 . The living condition indices $(\mathrm{J})$ were estimated to be between $2.8-2.1$ (Table 1 ). The maximum values of $\mathrm{J}$ were $2.7-$ 2.8 in the forest areas under oak stands. The pine-birch stands were characterized by a greater tolerance to environmental factors with living condition of 2.1. Similar plantations located away from the urban environment, the middle of the forest and in the control areas were leafier and exhibited less damage. The $\mathrm{J}$ values for these stands were 1.3 and 1.25 at the Istrinskyand Krasnaya Polyana Forestry experimental plots, respectively. This data shows that the proximity of the urban environment, mainly highways, has a negative effect on the state of the stand.

The anthropogenic load as an indicator for the ecological status of the stand a case study of the forest experimental station (FES)

of the Russian State Agrarian University of Moscow Agricultural Academy (RSAU-MAAT)

\begin{tabular}{|c|c|c|c|}
\hline $\begin{array}{l}\text { Number of the } \\
\text { experimental plot }\end{array}$ & Mainspecies, ageclass & $\begin{array}{l}\text { Index of the living } \\
\text { condition }(\mathrm{J}) \\
\text { of the forest stand }\end{array}$ & $\begin{array}{c}\text { Assessment } \\
\text { of an ecological state }\end{array}$ \\
\hline \multicolumn{4}{|c|}{ Sites with the minimum anthropogenicimpact } \\
\hline 6 & TheOakX-XII & 2.1 & $\begin{array}{l}\text { weakened condit } \\
\text { on of a plant }\end{array}$ \\
\hline 8 & The Oak VII-VIII & 2.5 & $\begin{array}{l}\text { weakened condition of a } \\
\text { plant }\end{array}$ \\
\hline 9 & The Pine with the birch IX-XI & 1.5 & healthy state \\
\hline \multicolumn{4}{|c|}{ Sites with the increased anthropogenicimpact } \\
\hline 11 & TheOakX-XII & 2.8 & $\begin{array}{l}\text { On the verge } \\
\text { of disintegration }\end{array}$ \\
\hline 7 & TheOak VII-VIII & 2.7 & $\begin{array}{l}\text { On the verge } \\
\text { of disintegration }\end{array}$ \\
\hline 10 & The Pine IX $-X I$ with the birch & 2.1 & $\begin{array}{l}\text { weakened } \\
\text { condition of a plant }\end{array}$ \\
\hline $\begin{array}{l}\text { IstrinskyForestry } \\
\text { (control) }\end{array}$ & The Pine with the birch. VIII-IX & 1.3 & $\begin{array}{l}\text { healthy condition } \\
\text { of a plant }\end{array}$ \\
\hline $\begin{array}{l}\text { Krasnaya Polyana } \\
\text { forestry (control) }\end{array}$ & TheOak VIII - IX & 1.25 & $\begin{array}{l}\text { healthy condition } \\
\text { of a plant }\end{array}$ \\
\hline
\end{tabular}


Soil-ecological characteristics under the experimental forest plantation at the forest experimental station (FES) of the Russian State Agrarian University of Moscow Agricultural Academy (RSAU-MAAT) with various anthropogenic load

\begin{tabular}{|c|c|c|c|c|c|c|c|c|c|c|}
\hline \multirow{3}{*}{$\begin{array}{l}\text { Number } \\
\text { of the expe- } \\
\text { rimental } \\
\text { plot }\end{array}$} & \multirow{3}{*}{$\begin{array}{c}\text { Bulk } \\
\text { density, } \\
\mathrm{g} \mathrm{cm}^{-3}\end{array}$} & \multirow[t]{3}{*}{$\mathrm{pH} \mathrm{KCl}$} & \multirow{3}{*}{$\begin{array}{c}\text { Organic } \\
\text { substance, } \\
\%\end{array}$} & \multicolumn{7}{|c|}{ The content of heavy metals (\%) in different extracts } \\
\hline & & & & \multicolumn{2}{|c|}{$\mathrm{Pb}$} & \multicolumn{3}{|c|}{$\mathrm{Zn}$} & \multicolumn{2}{|c|}{$\mathrm{Cu}$} \\
\hline & & & & $\mathrm{Ca}\left(\mathrm{NO}_{3}\right)_{2}$ & $1 \mathrm{~N} \mathrm{HCl}$ & $\mathrm{Ca}(\wedge$ & & $1 \mathrm{~N} \mathrm{HCl}$ & $\mathrm{Ca}\left(\mathrm{NO}_{3}\right)_{2}$ & $1 \mathrm{~N} \mathrm{HCL}$ \\
\hline \multicolumn{11}{|c|}{ Sites with the minimum anthropogenic impact } \\
\hline 6 & 0.84 & 4.10 & 4.06 & 47 & & 53 & 47 & 53 & 50 & 50 \\
\hline 8 & 0.82 & 4.25 & 4.67 & 47 & & 53 & 63 & 37 & 50 & 50 \\
\hline 9 & 0.83 & 3.90 & 5.49 & 36 & & 64 & 29 & 71 & 51 & 49 \\
\hline \multicolumn{11}{|c|}{ Sites with the increased anthropogenic impact } \\
\hline 7 & 1.22 & 4.20 & 10.12 & 64 & & 36 & 73 & 27 & 51 & 49 \\
\hline 10 & 1.26 & 3.75 & 8.98 & 60 & & 40 & 84 & 16 & 56 & 44 \\
\hline 11 & 1.30 & 4.35 & 6.3 & 54 & & 46 & 74 & 26 & 56 & 44 \\
\hline \multicolumn{11}{|c|}{ Wood sites with the minimum removal from an urban environment } \\
\hline $8 \ll O »$ & 0.81 & 4.20 & 4.45 & 31 & & 69 & 58 & 42 & 56 & 44 \\
\hline $4 \ll Ю »$ & 0.80 & 3.95 & 4.15 & 44 & & 56 & 65 & 35 & 37 & 63 \\
\hline
\end{tabular}

Significant differences in organic matter content were observed among the studied soil-ecological factors between the sites. The organic matter content in the soil under the plantations growing on the city border (experimental plots \#11, 7, 10) was significantly higher (about 50\%) than the organic content from the distant plots. This could indicate that there is potentially are duction of the most available forms of heavy metals (the exchangeable form sextracted with $\left.\mathrm{Ca}\left(\mathrm{NO}_{3}\right)_{2}\right)$ not a reduction of the less available (potentially available) forms (extracted with $1 \mathrm{~N} \mathrm{HCl}$ ). However,these correlations were not observed. Thus, theratio of the exchangeable to potentially available forms of heavy metals varies according to soil compaction. Our observations show that the higher the bulk density value, the greater the proportion of mobile forms of heavy metals, including an increasein the ratio of exchangeable forms. Therefore, it can be stated that the compaction factor is more significant than the humus content.

The soils were characterized as acidic with a $\mathrm{pH}$ range of 4 and 5 . The $\mathrm{pH}$ value varied in the upper humus horizon from 4.10 to 4.35 ; approximately a $7 \%$ difference. This difference, however, did nothave a significant impact on the degree of heavy metals mobility. The soils under the pine and birch stands growing in the middle of the forest (experimental plot \# 9) had pH of 3.9 and were classified as highly acidic (determined by a $\mathrm{pH}$ range of $3-4$ ) (Table 2). It was expected that the presence of organic matter and increased soil acidity would have also increased the degree of heavy metal mobility; however, this was not the case. The results showed that the mobilitywasactually largely affected by the compaction.

To confirm the importance of soil compaction as the driving factor of heavy metals mobility,soilsamples weretaken from the native stands growing on the city borderand analyzed for bulk density. The average value of bulk density was $0.8 \mathrm{~g} \mathrm{~cm}^{-3}$ (experimental plots \# 4 "Ю” and 8 “O”). The different phases of the heavy metals were also analyzed in these samples. In the forest plotswhere was minimal anthropogenic load, 
the content of the most available (exchangeable) forms (extracted with $\mathrm{Ca}\left(\mathrm{NO}_{3}\right)_{2}$ ) was significantly lower than the less mobile (potentially available) forms (extracted with $1 \mathrm{~N} \mathrm{HCl}$ ) (for $\mathrm{Pb}-44$ and $56 \%, \mathrm{Zn}-35$ and $65 \%, \mathrm{Cu}-37$ and $63 \%$, respectively). A similar ratiowas observed for $\mathrm{Pb}-31$ and $69 \%$. $\mathrm{Zn}-58$ and $42 \%$. $\mathrm{Cu}-44$ and $56 \%$ at the experimental plot \# 8 "O". Obtained results show, that in the absence of increased soil compaction, the percentage of the most mobile (exchangeable) form was significantly reduced.

The results show a significant reduction in the mobile forms of $\mathrm{Pb}$ in the forest areas that were subject tominimal recreational load in comparison with the high-density areas. This confirms that the soil compaction plays a dominant role in determining the degree of potentialcontamination hazard from the heavy metals. Soil compaction thus creates a sensitization effect, enhancing the impact of heavy metals; Pb contamination causing the greatest threat.

The increased heavy metal mobility in the soil affects the migration of contaminants into the plants. Considering that,the root system of a plant is the first biological barrier to toxins in polluted soils [12]; wehavestudied the heavy metal content in the roots of the tree species (Table 3 ).

Table 3

The heavy metal content in the tree roots depending on the degree

of anthropogenic load ( $\mathrm{mg} \mathrm{kg}^{-1}$ of dry matter)

\begin{tabular}{|c|c|c|c|}
\hline $\mathrm{N}$ of the trial area & $\mathrm{Cd}$ & $\mathrm{Zn}$ & $\mathrm{Cu}$ \\
\hline \multicolumn{4}{|c|}{ Sites with the minimum anthropogenic impact } \\
\hline 6 & $0.20+0.02$ & $22.35+1.05$ & $3.15+0.10$ \\
\hline 8 & $0.11+0.02$ & $7.12+0.10$ & $3.15+0.10$ \\
\hline 9 & $0.40+0.01$ & $47.25+2.80$ & $8.10+0.30$ \\
\hline \multicolumn{4}{|c|}{ Sited with the increased anthropogenic impact } \\
\hline 11 & $0.29+0.03$ & $35.75+1.40$ & $3.63+0.21$ \\
\hline 7 & $0.29+0.02$ & $10.50+0.14$ & $3.70+0.40$ \\
\hline 10 & $0.45+0.01$ & $62.30+2.80$ & $7.20+0.10$ \\
\hline Control (Istrinsky Forestry) Birch & $0.24+0.02$ & $32.60+2.60$ & $3.55+0.12$ \\
\hline Pine & $0.30+0.04$ & $22.00+2.50$ & $4.25+0.28$ \\
\hline
\end{tabular}

Increasing in anthropogenic load, heavy metal migration capacity (determined by biological uptake) in the plants also increased. The results ranged from 12 to $152 \%$ of plant heavy metal concentrations compared to the control plots, depending on the species composition of the stand. The maximum migration capacity was found in the root systems of 70-80-year-old oak tree stands (experimental plot \#7) and the minimum, in the roots of pine and birch phytocoenosis(experimental plots \#9, 10).

Soil properties undoubtedly affect the growth and condition of the plants. Soil-ecological characteristics studies adopted in forestry studies, such as humus content, soil acidity, and availability of nutrients, do not fully reflect the multifunction of forest and agricultural ecosystems; processes of transformation of organic matter in particular. It is therefore necessary to study the biological components with a strong focus on microorganismsalong with the compositional, physical and chemical properties of the soil. 
The behavior of microbial communities determines the mechanism of formation of sustainable forest and forest park ecosystems susceptible to a high anthropogenic load. This is especially important to consider in terms of the biodiagnostics and bioindications of soil when dealing with the issues related to the prevention of soil contamination. The data obtained on the status of these soil microbial relationships can be used for further research and monitoring of the forest and forest park landscapes [6].

The study of microbial components shows significant changes as a result of anthropogenicload. In the forest plotssusceptible to high anthropogenic load, the aerobic heterotrophic microorganisms sampled during different periods of vegetative growth exhibited a $7-10$-fold reduction in number. The number of ammonifiers from the oak plantations (X-XII age class) was reduced from 34.6 million of colony forming units (CFU) in $1 \mathrm{~g}$ of soil to 3.4 million. Similar reductions of biological activity were observed for other plantations in similar settings. Under the 70-80-year-olds phytocenoses of the same species, the numbers reduced from 37 million to 3.4 million of CFU. The pine and birch stands had reductions from 21.4 million to 2.5 million of CFU (Figure 1).

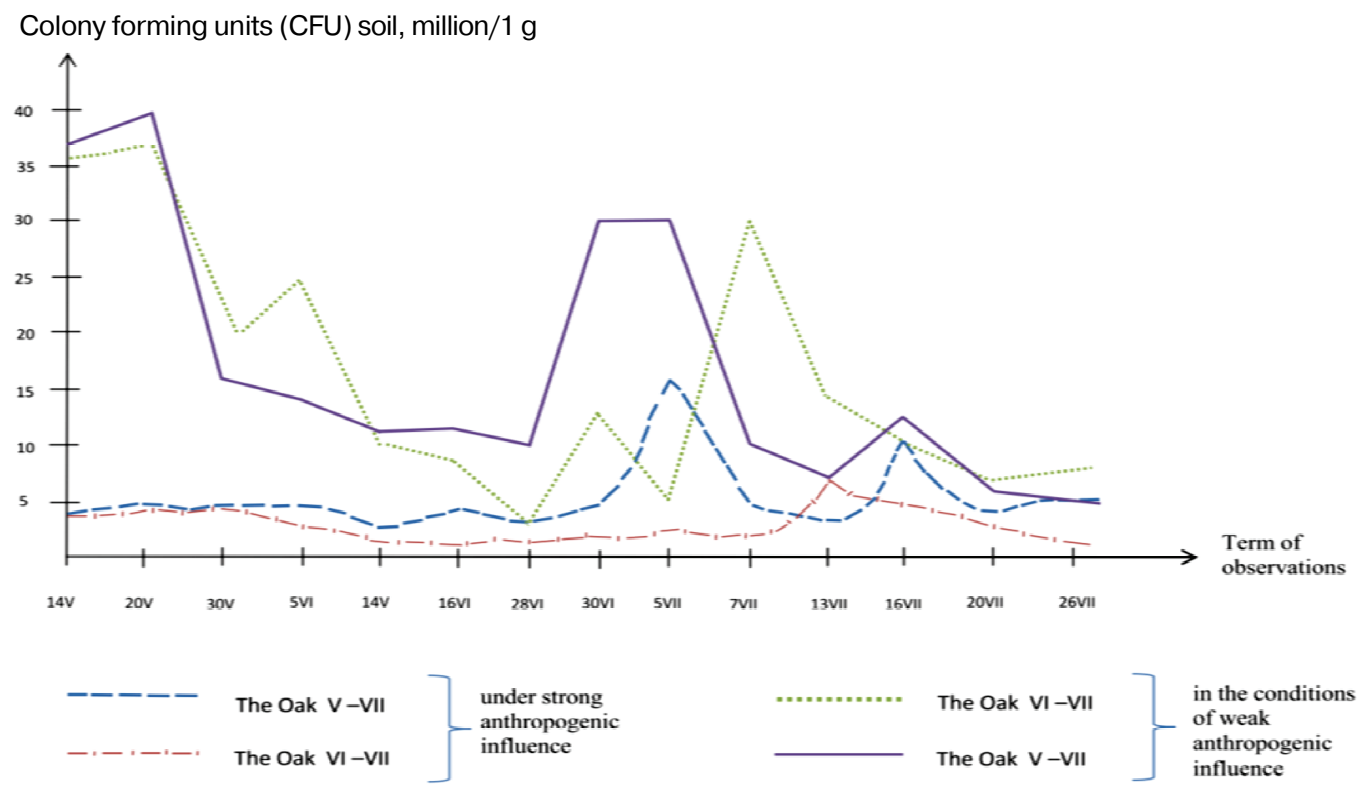

Figure 1. Changes in the number of microorganisms in the soil ammonifiers due to anthropogenic impacts (the upper $10 \mathrm{~cm}$ layer; million cells ( $\mathrm{g}$ of dry soil)

With the reduction in microbial activity, the systems' normal functions are hindered. In plots, were impaired reproductive function of actinomycetes, this fact was indicated by the absence of aerial mycelium on the surface of the colony, and they remained sterile. In addition, the black (Niger) actinomycetes group was revealed, changing the structure of microbial cenosis (Figure 2).

Reduction of species diversity of bacilli resulted indisturbance of the normal functioning of the soil-plant systems. In the forest soil located far from the urban area, $7-8$ heterotrophic aerobic spore-forming bacteria species were found whereas only $3-4$ species occurred under the plantation near the urban environment (Figure 3). 


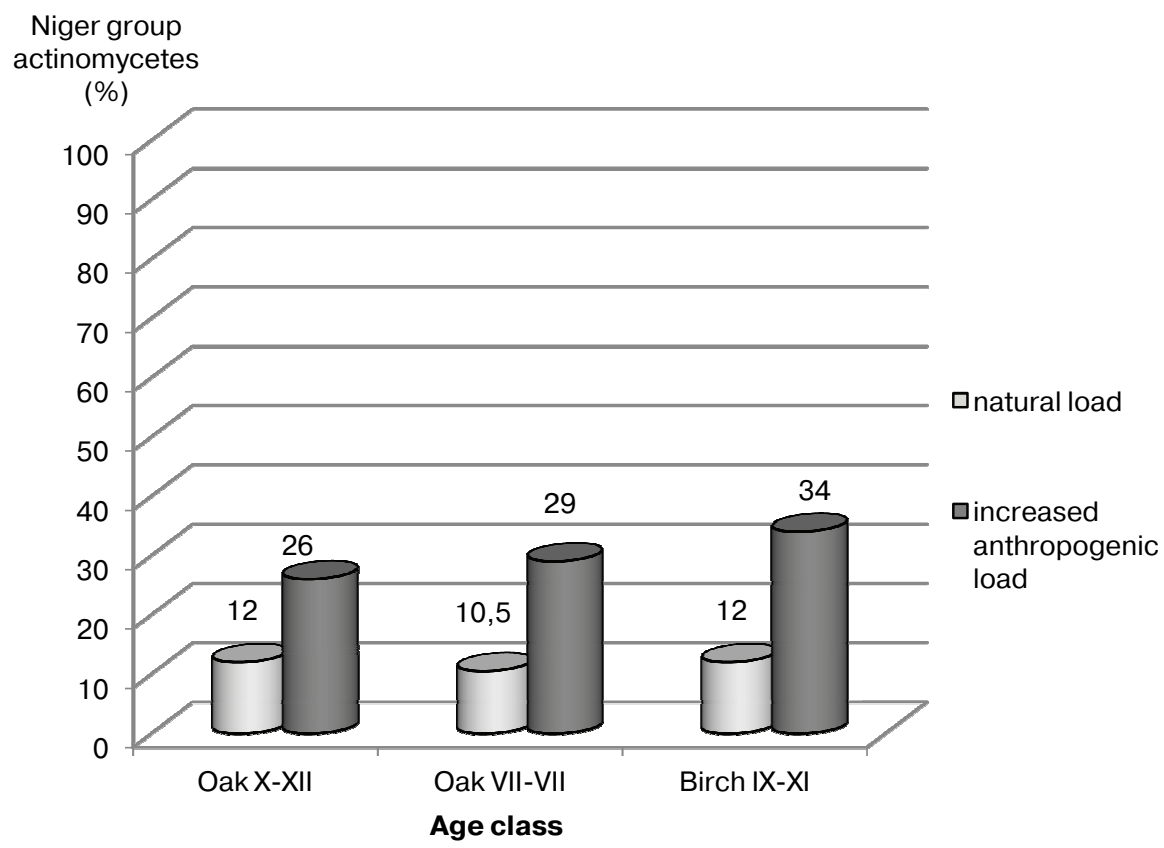

Figure 2. Percentage of theNiger groupactinomycetes under the plantations with different anthropogenic loads

\section{Increased anthropogenic load}

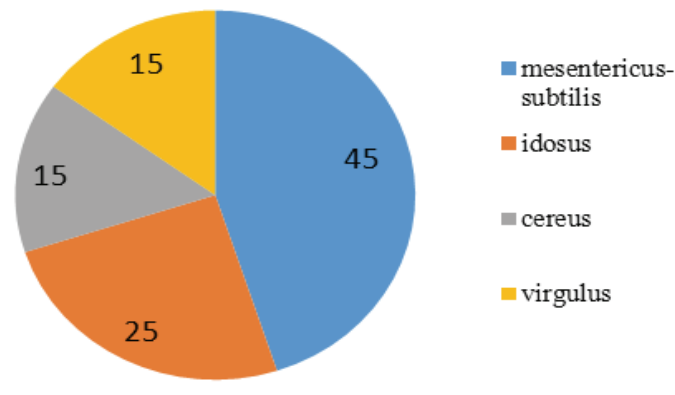

Natural anthropogenic load

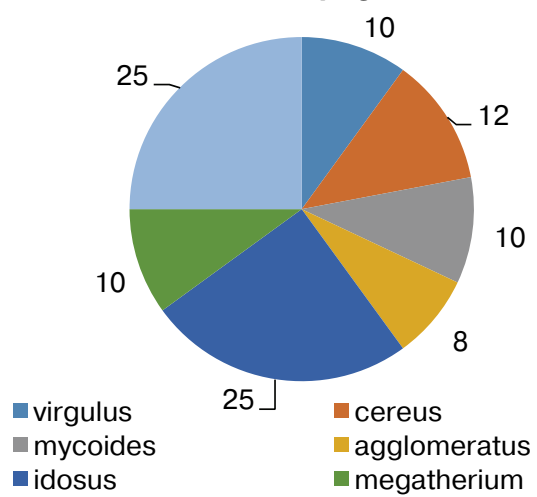

Figure 3. Species composition of bacilli in the soil under the tree plantations with various anthropogenic loads

\section{SUMMARY}

1. The proximity of the urban environment, mainly highways, has a negative effect on the state of the stand.

2. The greater bulk density value, the greater the proportion of mobile forms of heavy metals was observed including an increase in the ratio of exchangeable forms.

3. The maximum heavy metal migration capacity determined by biological uptake was found in the root systems of $70-80$-year-old oak tree stands and the minimum, in the roots of pine and birch phytocoenosis. 
4. The systems' normal functions were found to be hindered due to reduction in microbial activity. Reduction of species diversity of bacilli resulted in disturbance of the normal functioning of the soil-plant systems.

5. Soil compaction is a strong factor in increasing risk of heavy metal mobility.

6. Recreational activity causes a 2-3-fold increase in the density of the soil, resulting in poor aeration and significant heavy metal contamination, affecting the stability and functioning of the green spaces.

7. In order to prevent irreversible degradation of green spaces in urban areas, it is nessary to optimize conditions for their growth to improve the performance of their environmental functions.

\section{Acknoledgments}

The authors thank Harry Maisch IV for the assistance in editing.

(C) E.A. Dovletyarova, L.V. Mosina, A. Paltseva, Tatiana Morin, P.A. Petrovskaya, 2016

\section{REFERENCES}

[1] Cheng Z., A. Paltseva, I. Li, T. Morin, H. Huot, S. Egendorf, Z. Su, R. Yolanda, K. Singh, L. Lee, M. Grinshtein, Y. Liu, K. Green, W. Wai, B. Wazed, R. Shaw. 2015. Trace Metal Contamination in New York City Garden Soils. Soil Science. Volume 180. Number 4/5. April/May.

[2] EPA 747-R-98-001a. Final report sources of lead in soil: a literature review. February 1998.

[3] From the Surface Down. An Introduction to Soil Surveys for Agronomic Use. 2010. Second edition. USDA Natural Resources Conservation Service.

[4] Healthy soils are the basis for healthy food production. 2015. Food and Agriculture Organization of the United Nations. I4405E/1/02.15.

[5] Mosina L.V. Fundamentals of Toxicology: Training manual. M.: Russian State Agrarian University of Moscow Agricultural, 2013.

[6] Mosina L.V., Dovletyarova E.A. Microbiological diagnostics of problematic environmental situations at the recreational natural facilities // RUDN Journal of Agronomy and Animal Industries. № 5. M.: PFUR, 2015. P. 130-140.

[7] Mosina L.V., Dovletyarova E.A., Andriyenko T.N. The Forest experimental station of Russian State Agrarian University - Moscow Timiryazev Agricultural Academy as object of environmental monitoring of forest and forest-park landscapes of the megalopolis of Moscow. M.: PFUR, 2014.

[8] Mosina L.V., Dovletyarova E.A., Petrovskaya P.A. Microbiological assessment of a condition of forest and forest-park ecosystems // RUDN Journal of Agronomy and Animal Industries. № 4. M.: PFUR, 2015. P. 42-51.

[9] Ryan, J.A., Scheckl, K.G., Berti, W.R., Brown, S.L., Casteel, S.W., Chaney, R.L., Hallfrisch, J., Doolan, M., Grevatt, P., Maddaloni, M., Mosby, D., 2004. Reducing children's risk from lead in soil. Environ. Sci. Technol. 38 (1), 18A-24A.

[10] Soil Quality — Introduction. Soil Quality Information Sheet. USDA Natural Resources Conservation Service. Revised June 2001. Available at: http://soils.usda.gov/sqi.

[11] Su Chao. LiQin Jiang. WenJun Zhang. 2014. A review on heavy metal contamination in the soil worldwide: Situation, impact and remediation techniques. Environmental Skeptics and Critics. 3(2): 24-38.

[12] Vorhees. W.B. 1992. Wheel-induced soil physical limitations to root growth. In i and B.O. Stewart eds. Adv. Soil Sci 19:73-92.

[13] Wong Coby S.C. Xiangdong Li. Iain Thornton. 2005. Urban environmental geochemistry of trace metals. Review. Environmental Pollution 142 (2006) 1e16. doi: 10.1016/j.envpol.2005.09.004. 


\title{
ПОЧВЕННО-ЭКОЛОГИЧЕСКАЯ ХАРАКТЕРИСТИКА РЕКРЕАЦИОННЫХ ЛЕСНЫХ ЭКОСИСТЕМ В МЕГАПОЛИСЕ МОСКВА
}

\author{
Э.А. Довлетярова ${ }^{1}$, Л.В. Мосина ${ }^{2}$, А. Пальцева ${ }^{3,4,5}$, \\ Т. Морин ${ }^{3,5}$, П.А. Петровская ${ }^{1}$
}

${ }^{1}$ Российский университет дружбы народов

ул. Миклухо-Маклая, 8/2, Москва, Россия, 117198

${ }^{2}$ РГАУ-МСХА имени К.А. Тимирязева

ул. Тимирязевская, 49, Москва, Россия, 127550

${ }^{3}$ Бруклинский колледж Городского университета Нью-Йорка 2900 Бедфорд-авеню, Бруклин, Нью-Йорк, США, 11210

${ }^{4}$ Высшая школа Городского университета Нью-Йорка

Программа $\mathrm{PhD}$ наук о Земле и окружающей среде 365, 5-Авеню, Нью-Йорк, США 11016

${ }^{5}$ Институт городских почв Городской Университет Нью-Йорка (США)

2900 Бедфорд-авеню, Бруклин, Нью-Йорк, США, 11210

В условиях уникального лесного массива - Лесной опытной дачи Российского государственного аграрного университета - МСХА имени К.А. Тимирязева изучен в динамике комплекс почвенно-экологических показателей в системе почва—растение с использованием физических, химических и биологических (микробиологических) параметров на фоне загрязнения тяжелыми металлами (ТМ) и нерегулируемой рекреации. Исследования показали, что уплотнение почвы выступает мощным негативным фактором, вызывающим сенсибилизационный эффект, при котором увеличивается опасность действия тяжелых металлов. Возросшая рекреационная нагрузка, вызывающая 2-3-кратное возрастание плотности почвы, а также ее аэрорегулируемость на фоне существенного загрязнения тяжелыми металлами, вызывает комплекс факторов, негативно влияющих на устойчивость и функционирование «зеленых легких». Кроме того, с увеличением антропогенной нагрузки миграция ТМ в растения увеличивается. Максимальная миграционная способность установлена в корневой системе 70-80-летних древостоев дуба, минимальная - в корнях сосново-березового фитценоза. Нормально функционирование экосистемы было нарушено вследствие снижения микробиологической активности.

Ключевые слова: тяжелые металлы (ТМ), уплотнение почвы, микробиологическая активность, экологические функции почвы, жизненное состояние древостоя, рекреационная нагрузка 